\title{
Synthesis of cocoa butter triacylglycerols using a model acidolysis system
}

\author{
By Ozan Nazim Çiftçi ${ }^{\mathrm{a}}$, Sibel Fadiloğlu ${ }^{\mathrm{a}^{*}}$, Boleslaw Kowalski ${ }^{\mathrm{b}}$ and Fahrettin Göğüs ${ }^{\mathrm{a}}$
}

\author{
${ }^{a}$ University of Gaziantep, Faculty of Engineering, Department of Food Engineering, \\ 27310 Gaziantep, Turkey \\ ${ }^{\mathrm{b}}$ Warsaw University of Life Sciences, Department of Food Technology, Warsaw, Poland \\ ${ }^{*}$ Corresponding authorE-mail: fadiloglu @ gantep.edu.tr \\ Telephone: +903423172317 -Fax: +903423601105
}

\section{RESUMEN}

Síntesis de los triacilglicéridos de la manteca de cacao mediante un sistema modelo de acidolisis.

El efecto de parámetros de reacción como el ratio molar de sustratos, carga de enzima, contenido de agua o temperatura de reacción fueron estudiados en un sistema modelo de acidolisis para la síntesis de triglicéridos disaturados. Los ácidos grasos palmítico y esteárico se incorporaron a la molécula de trioleína (OOO) mediante la catálisis con una lipasa $s n-1,3$ específica para producir los tres triglicéridos (TAGs) mayoritarios de la manteca de cacao (CB): 1,3-dipalmitil-2-oleoil glicerol (POP), 1(3)-palmitil-3(1)-estearil-2glicerol (POS) and 1,3-diestearil-2-oleoil glicerol (SOS). Los TAGs producidos en cada reacción se analizaron por cromatografía líquida de alta eficacia (HPLC). Los mejores resultados (15.2\%, POP, $30.4 \%$ POS, $15.2 \%$ SOS) se obtuvieron empleando la relación molar de sustratos 1:3:3 (OOO ácido palmítico:ácido esteárico) y los parámetros de reacción: tiempo $10 \mathrm{~h}$, temperatura $45^{\circ} \mathrm{C}$, carga de enzima $20 \%$, contenido de agua $5 \%$. Los resultados obtenidos en este modelo podrían usarse para la optimización de la aplicación de la reacción acidolítica catalizada por lipasas en sistemas naturales para producir equivalentes de manteca (CBEs) de cacao.

PALABRAS CLAVE: Acidolisis - Equivalentes de manteca de cacao - HPLC - Lipasa sn-1,3 específica - Sistema modelo.

\section{SUMMARY}

Synthesis of Cocoa Butter Triacylglycerols Using a Model Acidolysis System

The effects of reaction parameters such as substrate mole ratio, reaction temperature, enzyme load, water content and reaction time were studied in a model enzymatic acidolysis system. Palmitic and stearic acids were incorporated into triolein $(\mathrm{OOO})$ under the catalysis of $s n-1,3$ specific lipase to produce the three major triacylglycerols (TAGs) in cocoa butter (CB), namely, 1,3-dipalmitoyl-2-oleoyl--glycerol (POP), 1(3)-palmitoyl-3(1)-stearoyl-2-oleoyl-glycerol (POS) and 1,3distearoyl-2-oleoyl-glycerol (SOS). TAG contents of the reaction products were analyzed by High Performance Liquid Chromatograph (HPLC). The best results (15.2\% POP, 30.4\% POS, $15.2 \%$ SOS) were obtained at 1:3:3 (OOO:palmitic acid:stearic acid) substrate mole ratio and reaction parameters: time $10 \mathrm{~h}$, temperature $45^{\circ} \mathrm{C}$, enzyme load $20 \%$, water content $5 \%$. The results obtained in this model system might be used for the optimization and application of lipase catalyzed acidolysis reactions in natural systems to produce cocoa butter equivalents (CBEs).

KEY-WORDS: Acidolysis - Cocoa butter equivalents HPLC - Model systems - 1,3 specific lipase.

\section{INTRODUCTION}

Improvement in the nutritional and functional properties of fats and oils is a popular topic of lipid biotechnology. For a long time, fats and oils have been modified enzymatically to produce structured triacylglycerols (STs) (Macrae and Hammond, 1985). STs can be manufactured to achieve regiospecific locations of fatty acids in the acylglycerols using specific lipases (Hoy and $\mathrm{Xu}$, 2001). Production of cocoa butter equivalents (CBEs) by enzymatic acidolysis with $s n-1,3$ specific lipases is a well studied example and such products could be used for food applications (Undurraga et al., 2001; Wang et al., 2006).

Cocoa butter (CB) is a highly valued ingredient primarily used in the chocolate industry. Due to its unique composition, CB gives desired physical properties to the manufactured product, e.g. gloss, snap, melting properties, etc Lipp et al. (2001). CB contains three main fatty acids: palmitic acid (C16), stearic acid (C18) and oleic acid (C18:1). $\mathrm{CB}$ is composed of three main TAGs: $21 \%$ POP (1,3-dipalmitoyl-2-oleoyl-glycerol); $40 \%$ POS(1(3)-palmitoyl-3(1) stearoyl-2-oleoylglycerol); $27 \%$ SOS (1,3-distearoyl-2-oleoylglycerol); with oleic acid at the sn-2 position of glycerol backbone (Saldana et al., 2002). CB melts over a narrow temperature range, from around 27 to $33^{\circ} \mathrm{C}$ (Smith, 2001). This particular melting behavior provides a cooling effect in the mouth when eaten (Lipp and Anklam, 1998). Because of the high cost and fluctuations in the supply and demand of $C B$, the industry has used alternatives with similar triacylglycerol (TAG) composition instead of CB. Alternatives are classified as (Lipp and Anklam, 1998):

(a) $\mathrm{CB}$ equivalent ( $\mathrm{CBE})$ : non-lauric plant fats, which are similar in their physical and chemical properties to CB and mixable with 
it in every amount without altering the properties of $\mathrm{CB}$;

(b) $\mathrm{CB}$ replacer $(\mathrm{CBR})$ : non-lauric fats with a distribution of fatty acids similar to $\mathrm{CB}$, but a completely different structure of the TAGs; only in small ratios compatible to CB.

(c) $\mathrm{CB}$ substitutes (CBSs): lauric plant fats, chemically different from $\mathrm{CB}$, with some physical similarities; suitable only to substitute CB to $100 \%$.

Production of CBEs by enzymatic acidolysis can be done by using $s n-1,3$ specific lipases that catalyze incorporation of stearic and palmitic acids to the sn1,3 positions of a starting oil containing oleic acid at the sn-2 position until a similar composition of CB is obtained. There are many studies reporting production of CBEs from different sources such as lard, tea seed oil, palm oil midfraction, sal fats, mango fat, illipe fat, kokum fat and shea oil (Undurraga et al., 2001; Wang et al., 2006; Sridhar et al., 1991; Lipp and Anklam, 1998). However, there are limited studies regarding the production of CBEs in a model system. The efficiency of the acidolysis reaction for the production of CBEs depends on reaction parameters namely substrate ratio, reaction temperature, reaction time, enzyme concentration and water content (Fomuso and Akoh, 1998). The effect of each parameter on the system must be determined and optimized both for quality improvements of the products and for the highest economical turnover.

This study reports the production of major TAGs of $\mathrm{CB}$ in a model enzymatic acidolysis system and determination of the effects of reaction parameters. For this purpose, acidolysis reactions of triolein with palmitic and stearic acids were carried out and the effects of various factors (substrate mole ratio, reaction temperature, reaction time, enzyme load and water content) on the production of POP, POS and SOS were studied.

\section{MATERIALS AND METHODS}

\subsection{Materials}

TAG standards (OOO, POP, POS and SOS) were obtained from Sigma Chemical Co. (St. Louis, MO). Palmitic ( $\geqslant 98 \%$ purity) and stearic acids ( $\geqslant 97 \%$ purity) were obtained from Merck (Darmstadt, Germany). Immobilized sn-1,3 specific lipase (Lipozyme IM, immobilized from Mucor miehei, 42 $\mathrm{U} / \mathrm{g}$ ) was purchased from Fluka Chemie $\mathrm{GmbH}$. Acetone, acetonitrile and $n$-hexane were purchased from Sigma-Aldrich. All solvents used were HPLC grade.

\subsection{Enzymatic acidolysis}

Acidolysis reactions of triolein with stearic acid and palmitic acid were performed at varying substrate mole ratios (OOO: palmitic acid: stearic acid; 1:1:1$1: 8: 8)$, enzyme loads $(5-20 \%$, based on weight of substrates), temperature $\left(40-60^{\circ} \mathrm{C}\right)$, water contents (0-40\%, based on weight of substrates) and time (0$72 \mathrm{~h}$ ). Initial weight of triolein in the reaction mixtures was $88.5 \mathrm{mg}(0.1 \mathrm{mmol})$. The weights of palmitic and stearic acids were adjusted according to the initial amount of triolein. The weight of substrates refers to the sum of the weights of triolein, palmitic and stearic acids in a reaction mixture. The reaction mixtures were dissolved in $5 \mathrm{~mL} n$-hexane in $50 \mathrm{~mL}$ Erlenmeyer flasks and incubated in a rotary incubator (New Brunswick Scientific, Nova 40, USA) at 200 rpm. $50 \mu \mathrm{L}$ aliquots were withdrawn at certain time intervals from the reaction mixtures into glass vials and stored at $-20^{\circ} \mathrm{C}$ prior to analysis. All reactions were conducted in duplicate. The standard deviations of the results ranged from 0.1 and 2.8 for all experiments conducted.

\subsection{HPLC analyses}

The time course of the acidolysis reactions was followed by analyzing the reaction mixtures for their POP, POS and SOS contents by a reversed phase HPLC. The HPLC system consisted of a quadratic pump (model LC-10ADVP; Shimadzu, Japan) equipped with a column (Sphereclone $5 \mu$ ODS (2), 250 x $4.6 \mathrm{~mm}$; Phenomenex, USA) with an accompanying guard column $(40 \times 3-\mathrm{mm}$ id) of the same phase and an ultraviolet (UV) detector (Hewlett Packard Series 1100). Elution was monitored by UV absorbance at $215 \mathrm{~nm}$. The mobile phase consisted of acetone and acetonitrile $(50: 50, \mathrm{v} / \mathrm{v})$ with a flow rate of $1.0 \mathrm{~mL} / \mathrm{min}$. The column temperature was set at $50^{\circ} \mathrm{C}$ with a column heater (Eppendorf $\mathrm{CH}-30$ column heater).

\subsection{Statistical analysis}

Statistical analysis of the obtained data was carried out using an SPSS (version 10.0) package program at $95 \%$ confidence interval (SPSS 1999).

\section{RESULTS AND DISCUSSION}

The effect of the mole ratio of triolein to palmitic and stearic acids was studied from $1: 1: 1$ to $1: 8: 8$ at a constant enzyme load (10\%, based on weight of substrates) and at a temperature of $45^{\circ} \mathrm{C}$ to determine the upper limit of substrate mole ratio. Figure 1 shows the relationship between percent conversion and substrate ratio. The percent conversion of triolein to target TAGs was defined as the ratio of the content of target TAGs (POP+POS+SOS) to the content of initial triolein times one hundred.

Percent conversion increases with increasing substrate ratio and then declines when substrate ratio increases further. The highest product formation was obtained at 1:3:3 substrate ratio. Therefore, it seems that an excess of palmitic and stearic acids above a molar ratio of 1:3:3 diminishes 


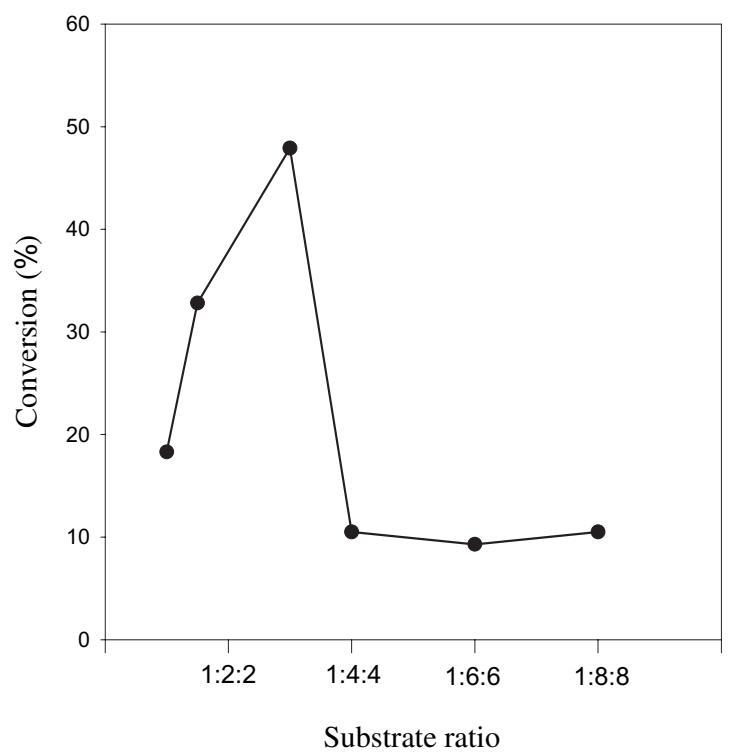

Figure 1

Effect of substrate ratio on percent conversion of triolein into POP, POS and SOS. Each mixture was incubated at $45^{\circ} \mathrm{C}$ for $10 \mathrm{~h}$ with $10 \%$ enzyme (based on weight of reactants, $\mathrm{w} / \mathrm{w}$ ). the reaction rate. This result is consistent with the findings of (Yankah and Akoh 2005), and Paez et al. (2003). Excess free fatty acids in the medium acidify the enzyme layer because of high levels of free or ionized carboxylic acid groups or cause desorption of water from the interface which causes a decrease in the activity of the enzyme (Kuo and Parkin, 1993). In addition, high substrate ratios are economically unfeasible, because purification of the products would require a cost-increasing extra separation step. Therefore, 1:1:1, 1:1.5:1.5 and 1:3:3 substrate ratios were studied for further investigations.

Figures $2 a, b, c$ and $d$ show the effect of temperature on TAG formation. The reactions were carried out at different substrate ratios and constant enzyme load (10\%). A similar trend of product formation regardless of temperature can be seen. The highest yield at $45^{\circ} \mathrm{C}$ was obtained at $24 \mathrm{~h}$. However, the time needed for the highest yield was $48 \mathrm{~h}$ at 40 and $50^{\circ} \mathrm{C}$, and $72 \mathrm{~h}$ at $60^{\circ} \mathrm{C}$. There was no significant difference $(P>0.05)$ between the highest TAG contents obtained from the reactions at 40,45 and $50^{\circ} \mathrm{C}$. Because the lower temperature and the shorter time were reported to be
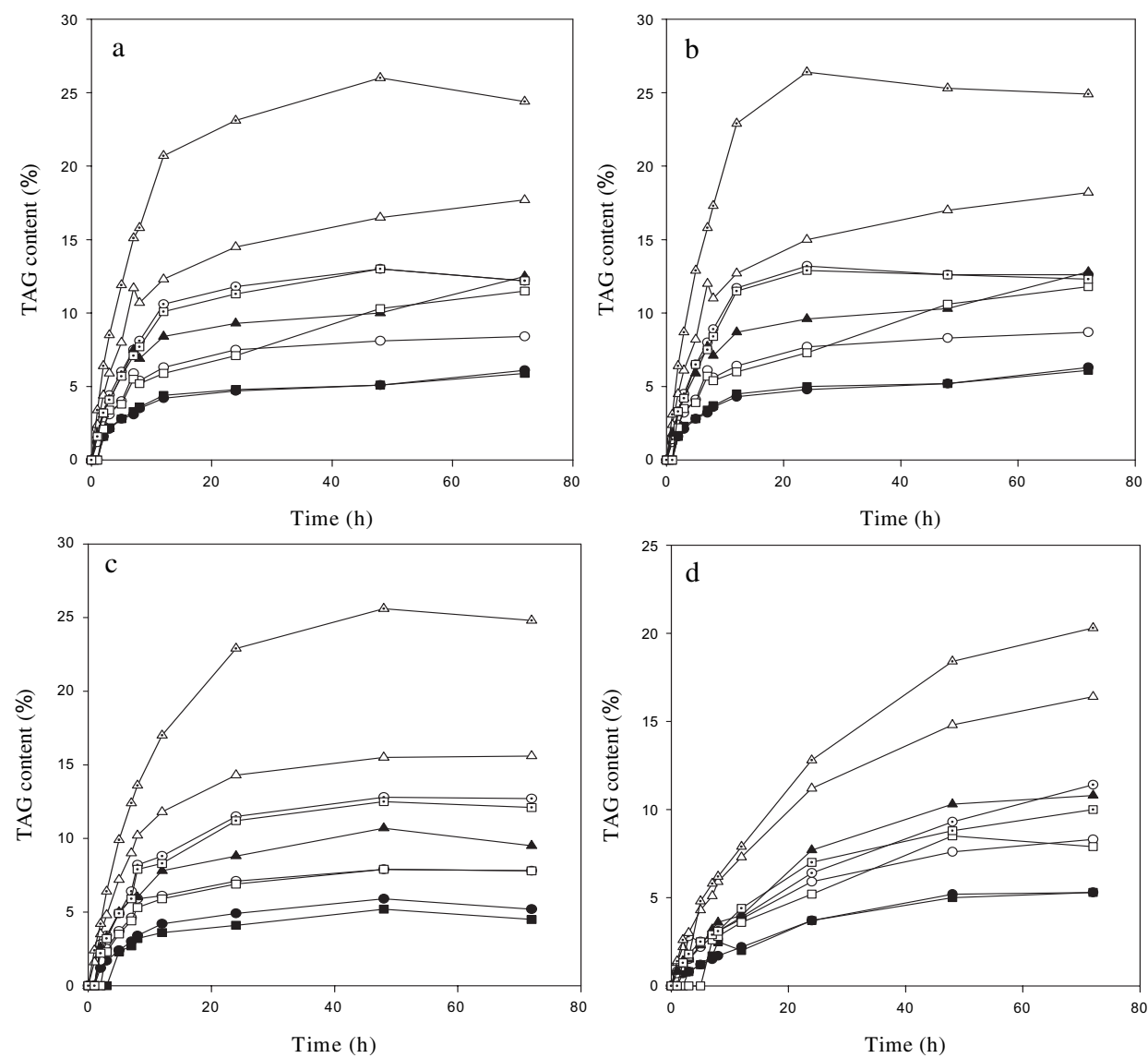

Figure 2

Effect of temperature on product formation at different substrate ratios. Each mixture was incubated with $10 \%$ enzyme (based on weight of reactants, w/w). POP $\%$ at $1: 1: 1$ substrate ratio $(\bullet)$, POP $\%$ at $1: 1.5: 1.5$ substrate ratio $(\bullet)$, POP $\%$ at $1: 3: 3$ substrate ratio $(\odot)$; POS $\%$ at $1: 1: 1$ substrate ratio $(\Delta), P O S \%$ at $1: 1.5: 1.5$ substrate ratio $(\Delta), P O S \%$ at $1: 3: 3$ substrate ratio $(\Delta)$; SOS\% at $1: 1: 1(\boldsymbol{(})$, SOS $\%$ at $1: 1.5: 1.5$ substrate ratio (), SOS $\%$ at $1: 3: 3$ substrate ratio $(\bullet)$. (a) $40^{\circ} \mathrm{C}$; (b) $45^{\circ} \mathrm{C}$; (c) $50^{\circ} \mathrm{C}$; (d) $60^{\circ} \mathrm{C}$. 
advantageous both in terms of the prevention of acyl migration (Xu, 2000) and economy, $45^{\circ} \mathrm{C}$ was chosen as the best temperature to study in the further experiments. Acyl migration is a problem of batch system acidolysis reactions which involves migration of acyls from sn-1,3 to sn-2 positions but also occurs with migration of acyls from the sn-2 into the sn-1,3 positions Yang et al. (2005).

The contents of target TAGs increased with increasing substrate ratios (Figures $2 a, b, c, d$ ). The yields obtained at limiting amount of substrate ratio $(1: 1: 1)$ are the lowest among all substrate ratios studied. This may be due to the need for an excess amount of fatty acid for better incorporation. The amounts of POP and SOS formed are very close to each other at all studied conditions. This results from the incorporation of the same amounts of palmitic and stearic acids to positions 1 and 3 of triolein. So, it can be concluded that Lipozyme IM does not have higher reactivity and/or selectivity of palmitic acid over stearic acid or vice versa. The production of the highest amount of POS and equal amounts of POP and SOS make the composition of the product very similar to the original $\mathrm{CB}$. The best result was obtained at 1:3:3 substrate ratio, $45^{\circ} \mathrm{C}$ and $24 \mathrm{~h}$ with a product composition of $13.2 \%$ POP, $26.4 \%$ POS and $12.9 \%$ SOS. Therefore, 1:3:3 substrate ratio and $45^{\circ} \mathrm{C}$ reaction temperature were used for the subsequent experiments.

The effect of enzyme load on TAG formation was investigated for $5 \mathrm{~h}$ reaction time (Figure 3 ). Increase in enzyme load has no effect on the yield of product after a certain reaction time, therefore optimum enzyme load was determined at this early stage of the reaction. As shown in Figure 3, increased enzyme load accelerated the reaction rate and

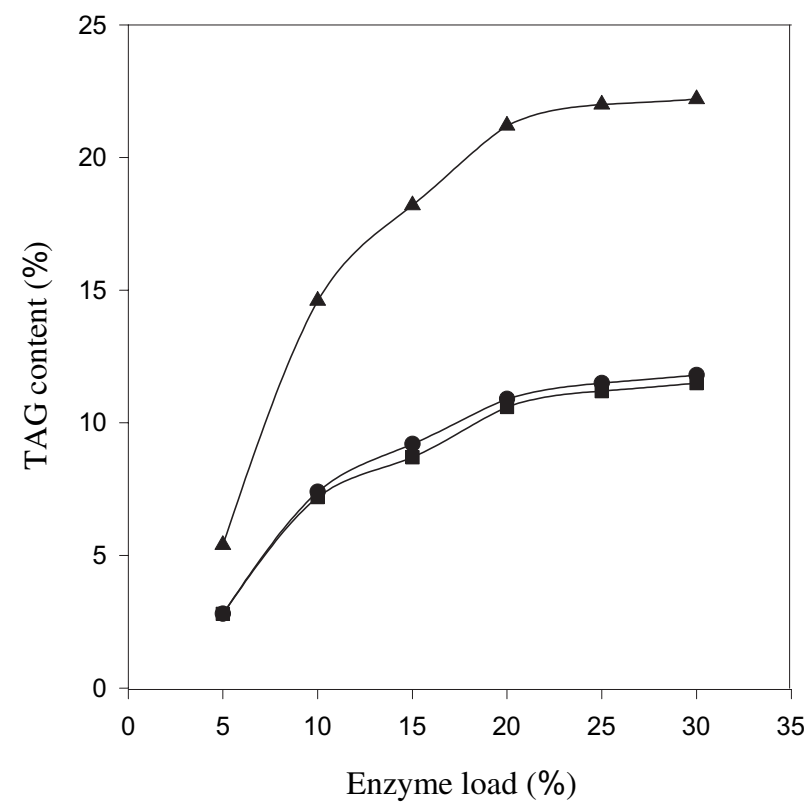

Figura 3

Effect of enzyme load on product formation. Each mixture was incubated at 1:3:3 substrate ratio at $45^{\circ} \mathrm{C}$ for $5 \mathrm{~h}$. POP $\%$ $(\bullet)$, POS \% (A) and SOS \% (•). improved the incorporation of acyl donors under given conditions. The relationship between the acyl incorporation and the amount of added lipase was not linear. Increasing the amount of lipase above $20 \%$ (based on weight of substrates) had no significant effect $(P>0.05)$ on substrate conversion.

Figure 4 shows the change in TAG content with time at $20 \%$ enzyme load. POP, POS and SOS contents increased up to $10 \mathrm{~h}$ and remained constant after this time. TAG contents were 12.1, 24.5, and $12.1 \%$ for POP, POS and SOS, respectively, by the end of $10 \mathrm{~h}$. However, a minimum of $24 \mathrm{~h}$ was required to obtain similar TAG contents if the enzyme load is $10 \%$. It has been found that an enzyme load of $20 \%$ compared to that of $10 \%$ decreased the reaction time significantly $(P<0.05)$.

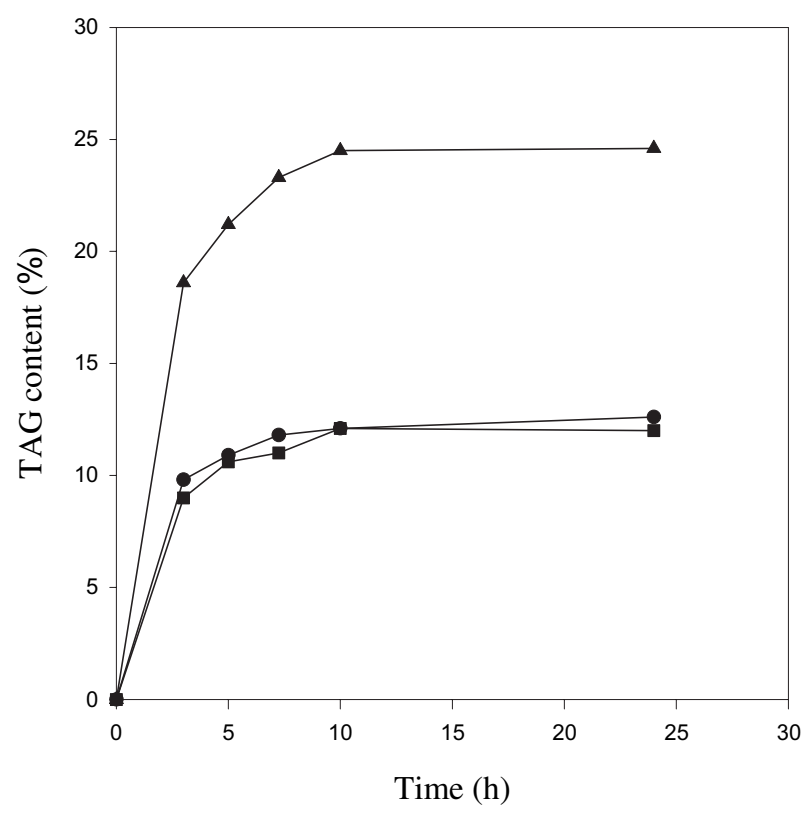

Figura 4

Change in TAG content (\%) with time at $20 \%$ enzyme load. Each mixture was incubated at $1: 3: 3$ substrate ratio at $45^{\circ} \mathrm{C}$ for 24 h. POP \% (•), POS\% (山) and SOS\% (•).

As shown in Figure 5, water content has a significant effect on the acidolysis reaction. TAG content attained a peak at $5 \%$ and decreased with further increase in water content. The amount of water added was based on the weight of substrates. (Sellappan and Akoh 2000) have also reported that it would be better to calculate the amount of water based on weight of substrates instead of the weight of the enzyme. Lipases need a certain amount of water for activation. But an excess of water will shift the reaction to hydrolysis instead of synthesis. The amount of water in the reaction system must be controlled for the orientation of the reaction process and for better results. Optimum water content depends on the reaction system, e.g., type of lipase, substrate, support and solvent Mojovic et al. (1993). So, it must be determined for each particular experiment design. 


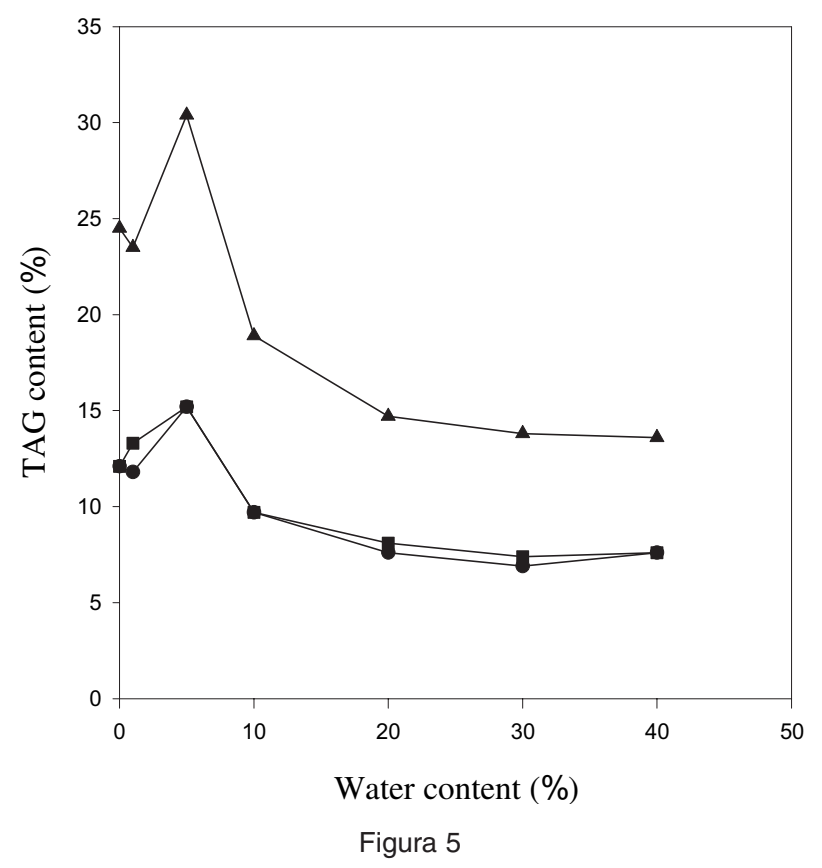

Effect of water content on product formation. Each mixture was incubated at $1: 3: 3$ substrate ratio at $45^{\circ} \mathrm{C}$ for $10 \mathrm{~h}$ with $20 \%$ enzyme (based on weight of reactants, w/w). POP\% (•), POS\% (ム) and SOS\% (-).

\section{CONCLUSIONS}

The best result (15.2\% POP, $30.4 \%$ POS, $15.2 \%$ SOS) were obtained at 1:3:3 (OOO: palmitic acid:stearic acid) substrate mole ratio and reaction parameters: time $10 \mathrm{~h}$, temperature $45^{\circ} \mathrm{C}$, enzyme load $20 \%$, water content $5 \%$. Under these conditions, triolein content decreased from an initial value of $35.3 \%$ to a residual amount of $9.1 \%$.

\section{ACKNOWLEDGEMENTS}

The research was supported by Scientific Research Projects Governing Unit (BAPYB) of University of Gaziantep

\section{REFERENCES}

Fomuso LB, Akoh CC. 1998. Structured lipids: Lipase catalyzed interesterification of tricaproin and trilinolein. JAOCS 75, 405-410.

Hoy CE, Xu X. 2001. Structured triacylglycerols, Gunstone F.D. (Ed.) Structured and Modified Lipids, 209-239. Marcel Dekker Inc., New York.

Kuo SJ, Parkin KL. 1993. Substrate preferences for lipase mediated acyl-exchange reactions with butter oil are concentration-dependent. JAOCS 70, 393-399.

Lipp M, Anklam E. 1998. Review of cocoa butter and alternative fats for use in chocolate-Part $A$. Compositional data. Food Chem., 62, 73-97.

Lipp M, Simoneau C, Ulberth F, Anklam E, Crews C, Prereton P, Greyt W, Schwack W, Wiedmaier C.
2001. Composition of genuine cocoa butter and cocoa butter equivalents. J. Food Compos. Anal. 14, 399-408.

Liu KJ, Shaw JF. 1997. Synthesis of cocoa butter equivalent by lipase-catalyzed interesterification in supercritical carbon dioxide. JAOCS 74, 14771482.

Macrae AR, Hammond RC. 1985. Present and future application of lipases. Biotechnol. Genetic Eng. Rev. 3, 193-217.

Mojovic L, Siler-Marinkovic S, Kukic G, VunjakNovakovic G. 1993. Rhizopus arrhizus lipasecatalyzed interesterification of the midfraction of palm oil to a cocoa butter equivalent fat. Enzyme Microb. Tech. 15, 438-443.

Paez BC, Medina AR, Rubio FC, Cerdan LE, Grima EM. 2003. Kinetics of lipase-catalyzed interesterification of triolein and caprylic acid to produce structured lipids. J. Chem. Technol. and Biot. 78, 461-470.

Saldana MDA, Mohamed RS, Mazzafera P. 2002. Extraction of cocoa butter from Brazilian cocoa beans using supercritical $\mathrm{CO}_{2}$ and ethane. Fluid Phase Equilibr. 194-197, 885-894.

Sellappan S, Akoh CC. 2000. Enzymatic acidolysis of tristearin with lauric and oleic acids to produce coating lipids. JAOCS 77, 1127-11132.

Smith KW. 2001. Cocoa butter and cocoa butter equivalents, in Gunstone FD (Ed.) Structured and Modified Lipids, Marcel Dekker, Inc., New York, pp. 401-422.

SPSS. 1999. SPSS 10.0 for Windows, Statistical Software, SPSS Inc., Chicago, IL.

Sridhar R, Lakshminarayana G, Kaimal T. 1991. Modification of selected Indian vegetable fats into cocoa butter substitutes by lipase-catalyzed ester interchange. JAOCS 68, 726-730.

Undurraga D, Markovits A, Erazo S. 2001. Cocoa butter equivalent through enzymic interesterification of palm oil midfraction. Process Biochem. 36, 933-939.

Wang H.X, Wu H, Ho C.T, Weng X.C. (2006). Cocoa butter equivalent from enzymatic interesterification of tea seed oil and fatty acid metyl esters. Food Chem. 97, 661-665.

Xu X. 2000. Enzymatic production of structured lipids: Process reactions and acyl migration. INFORM 11, 1121-1131.

Yang T, Fruekilde MB, Xu X. 2005. Supression of acyl migration in enzymatic production of structured lipids through temperature programming. Food Chem. 92, 101-107.

Yankah VV, Akoh CC. 2000. Lipase-catalyzed acidolysis of tristearin with oleic or caprylic acids to produce structured lipids. JAOCS 74, 495-500.

Zhao H, Lu Z, Bie X, Lu F, Liu Z. 2005. Lipase catalyzed acidolysis of lard with capric acid in organic solvent. J. Food Eng.78, 41-46.

Recibido: $13 / 2 / 08$ Aceptado: 10/3/08 